\title{
16 Hardrock mining, climate change, and conflict: reflections through the lens of Catholic social thought
}

\author{
William N. Holden \& \\ Caesar A. Montevecchio
}

\section{Hardrock mining and climate change}

Metals such as copper, gold, lead, nickel, silver, and zinc are products of "hardrock mining," which is often overlooked in discussions of climate change. As Benjamin Auciello $(2019,6)$ points out, analyses and policies that address extractive industries and climate change tend to focus on fossil fuels, rarely foregrounding metal and mineral mining. While hardrock mining may not extract products that emit greenhouse gases, it has important interfaces with climate change, in how it relates to climate vulnerability, and in how it is central to low-carbon growth. This chapter considers the relevance of these interfaces for conflict and peace and analyzes them through the lens of Catholic social thought and praxis. This includes climate injustice and disparate climate impacts between the Global North and Global South; "extractivism" and harmful senses of development; violence against human rights and environmental defenders; and unique questions of uranium mining and the specter of nuclear arms.

\section{Metals mining and climate vulnerability}

Mining is an activity with substantial environmental consequences, such as siltation, contamination, and depletion of water, air pollution, and deforestation (see Holden and Jacobson 2012, 59-76). Most are exacerbated by climate change. One of the most serious is acid mine drainage. Rocks containing desirable minerals are often found in sulfide ore deposits; when these are exposed to water and oxygen, they release sulfuric acid. As this continues, heavy metals such as arsenic, lead, and mercury can be mobilized.

The principal method of managing acid mine drainage is to place mining wastes (or "tailings") under water behind a tailings dam in an anaerobic environment. For this to be effective water must always be over the material; should a tailings dam fail, contaminants would be released. Since the geochemical processes of acid mine drainage operate on a geologic time 
scale, these dams require perpetual attention. And over time, climate change will present more and more problems, such as by bringing more heat waves, droughts, and wildfires. ${ }^{1}$ There will also be stronger tropical cyclones and heavier rainfall increasing the risk of dam failures (National Academies of Sciences, Engineering, and Medicine, 2016).

Mining companies will be increasingly frustrated in searching for technological solutions to these and other environmental risks from climate change. In planning mines and waste storage, mining engineers will find it more and more difficult to rely upon stationarity, the idea that precipitation levels can be measured within upper and lower limits determined by climatic history. With climate change, stationarity has become unreliable as a principle of water management (Milly et al. 2008). Mine waste storage facilities must now be constructed to accommodate worst-case scenarios, not what the climatic records indicate as the highest rainfall levels likely to occur; given the uncertainty surrounding the rapidity of climate change, this determination will be difficult (Holden 2015, 11).

\section{Metals mining and low carbon growth}

The prevention of catastrophic climate change requires a transition away from fossil fuels and towards renewable energy. But dozens of mined metals are employed in renewable technologies (Dominish, Florin, and Teske $2019,16)$. For example, aluminum and copper are required for wind turbines, photovoltaic panels, and rechargeable car batteries; silver, selenium, and tellurium for photovoltaic panels; and cobalt, lithium, and nickel for rechargeable car batteries. Auciello $(2019,13)$ points out: "Mining companies stand to benefit by positioning themselves as key actors in the transition. They are taking advantage of the projected increase in critical metals to greenwash and justify new operations, regardless of whether their output will be used in renewable energy technologies or not."

Another mineral which might see increased demand as the world makes a transition away from fossil fuels is uranium, a fuel for nuclear power plants. The advantage of nuclear energy lies in the tremendous amount of energy generated by a relatively small quantity of uranium. Uranium has a high energy density per unit of fuel and one gram can produce as much energy as three tons of coal (Percebois 2003, 102). Ecologist James Lovelock has declared nuclear energy the only immediately available energy source not causing global warming (Marshall 2005, 1169). A 676-megawatt Canadian Deuterium Uranium reactor will reduce carbon dioxide $\left(\mathrm{CO}_{2}\right)$ emissions by about 1.2 million tons per year if it displaces a coal powered plant (Morrison 2001, 46).

Since France produces approximately $80 \%$ of its electricity from nuclear power, it has the lowest $\mathrm{CO}_{2}$ per unit of gross domestic product of any country in the world. If the world's $\mathrm{CO}_{2}$ emissions were as low as France's, they would be reduced by half (Richter 2006, 15). Indeed, the 


\section{2}

construction of 3,000 to 3,200 new nuclear power plants worldwide by 2050 could stabilize $\mathrm{CO}_{2}$ concentrations at twice pre-industrial levels, notwithstanding a $50 \%$ increase in world population and a $50 \%$ increase in per capita energy consumption (Macfarlane 2003). When Germany retired all its nuclear power plants after the 2011 accident at Fukushima, it saw a significant and rapid spike in $\mathrm{CO}_{2}$ emissions. By displacing fossil fuels, nuclear power has potential to slow down, or possibly even avert, catastrophic climate change.

There are risks in nuclear power, as demonstrated by the accidents at Fukushima and at Chernobyl in 1986. At Chernobyl, the official death toll was 47 , although some estimates go as high as 4,000 when considering radiation effects. At Fukushima not one person died and, in the words of David Wallace-Wells $(2019,183)$, "Had none of the 100,000 living in the evacuation zone ever left, perhaps a few hundred might have ultimately died of cancers related to the radiation." But for comparison's sake, it is estimated that 10,000 people die every day from the particulate matter emitted by burning carbon (183). At the very least, this comparison calls into question whether the risk of such events is a worthwhile tradeoff for lowered carbon emission.

Unfortunately, one of the largest disadvantages of nuclear energy is the environmental impact of uranium mining. This is where nuclear energy can have some of its most serious environmental effects. Uranium mining causes the same environmental problems as other types of hardrock mining, but also involves radioactivity. Uranium mining can release radionuclides into the atmosphere through the crushing and grinding of ore, from fugitive dust emissions, and from the release of radon gases (Thomas and Gates 1999, 527). Moreover, uranium radioactivity and acid mine drainage are not problems that exist simultaneously but independently of each other; rather, they have a perverse synergy in that acid mine drainage leads to the further dissolution of radionuclides, enhancing the radioactivity given off by the uranium (Fernandes et al. 1998; Ripley et al. 1996, 201). According to Saleem Ali (2003, 109), "In terms of both short-term and long-term environmental impact, uranium mining is by far the most environmentally problematic of any mining activity-owing to the simple fact that radioactivity of the ore presents an intangible that cannot be chemically mitigated."

\section{Hardrock mining, climate change, and challenges to peace}

Mining is a leading cause of socio-environmental conflict (Auciello 2019, 17). As of August 21, 2019, the Environmental Justice Atlas documented 2,865 cases of socio-environmental conflict, with 587 related to mining; of these, 260 are related to the extraction or processing of metals. That is a lower number than combined fossil fuel-related conflicts (oil, 279; coal, 212; gas, 153), but metals-mining conflicts could well overtake fossil fuel-related 
conflicts if the extractive frontier expands towards the metals necessary for renewable energy (Environmental Justice Atlas n.d.). And though it does not register as socio-environmental conflict, the risk of nuclear arms that is presented by uranium mining is another important challenge for peace. The following considers some of the specific factors involved in these situations and responds to them with insights from Catholic social thought and praxis.

Pope Francis is the first pope from the Global South, and his affection for the environment became apparent when Laudato $S i$ ' was released. Its predominant theme is "integral ecology" and how this responds to the dangers and injustices created by environmental degradation, including the seriousness of climate change. Francis $(2015, \$ 26)$ affirms the pursuit of renewable energy: "There is an urgent need to develop policies so that, in the next few years, the emission of carbon dioxide and other highly polluting gases can be drastically reduced, for example, substituting for fossil fuels and developing sources of renewable energy." Although Francis does not address using nuclear energy as a method of providing low-carbon electricity, he does intimate that the use of less harmful alternatives or other short-term solutions, which could include nuclear energy, may be necessary $(\$ 165)$. But throughout, Francis's teaching on the environment demonstrates constant awareness of the possible injustice created as those in the Global South bear the brunt of the impact of worsening climate change and of the shortcomings of the technocratic solution models attached to mining and energy.

\section{North-south climate injustice and the need for subsidiarity and solidarity}

Relying on hardrock minerals to alleviate climate change's effects is highly problematic as it perpetuates an economic and cultural paradigm inseparable from injustice, conflict, and environmental degradation. It is also a paradigm that maintains colonial disparities between the Global North and the Global South, as much of the mining of those minerals occurs in the latter while the consumption of them will occur in the former. This can be approached through the perspective of climate injustice, how some people enjoy the benefits of energy use and other emissions-generating activities, while others disproportionately suffer the burdens of climate change (Bell 2013, 190). Specifically, this means that locations in the Global South where the minerals necessary for a transition to a low-carbon future are found bear an unjust and unequal amount of their cost (Auciello 2019, 7).

The Democratic Republic of the Congo (DRC) exemplifies these dynamics. As outlined in the chapter by Rigobert Minani, privatization of the mining industry in the DRC amplified economic and political insecurity and significantly exacerbated conflict. These problems were particularly concentrated in the eastern part of the country, where most of the country's 
cobalt reserves are located and where mining companies engaged with and enriched rebel groups that had gained more influence in the region than the national government for a period beginning in the late 1990s. Cobalt is essential for renewable energy, and as demand for it has rapidly increased, tremendous human and environmental costs have been imposed on the people of the DRC (Noriyoshi 2020). This mining supports solutions for climate change in the Global North, but does so while passing a great burden to the Global South, disempowering already vulnerable populations and worsening violent conflict.

Pope Francis's teaching has shown great concern for this kind of disparity. Querida Amazonia, Francis's apostolic exhortation following the 2019 Synod on the Amazon, applies Laudato Si's ecological framework to the environmental justice challenges of the region. The document predominantly focuses on indigenous peoples-both their suffering and victimization, and the inherent value of their heritage, which can be a source of wisdom for those in the throes of globalized capitalism and neoliberal ideas of development. And it does so while placing that plight under the rubric of colonialism, as well as connecting it to global environmental problems (Francis 2020, $\$ 14,48$ ).

Francis observes that the "techno-economic" power structures rooted in the Global North are the primary drivers of extractive and other projects endangering the Amazon and are a threat to "overwhelm not only our politics, but also freedom and justice" $(\$ 52)$. Part of his solution, rooted in the principle of subsidiarity, is to empower national leaders to protect ecologically sensitive areas against "huge global economic interests" that would otherwise "internationalize" the Amazon (\$50). He supports free, prior, and informed consent, the right of communities to say no to projects and propose development alternatives, and the need for legal frameworks to protect and enforce such rights (\$51-52). But more deeply, he appeals to the wisdom of indigenous cultural heritage and local systems of knowledge as sources for helping to make better decisions about how land is developed and used. Such sources can help awaken a sense of ecological spirituality, engendering greater ecological care $(\$ 42)$.

In his chapter, Vincent Miller outlined a way for the Catholic Church to use its ecclesial networks to help develop solidarity between the Global North and supply chain origin points in the Global South. If Querida Amazonia's "ecclesial dream" of a church that learns from indigenous peoples in the Amazon can be actualized $(\$ 28-40)$, then the networks of solidarity described by Miller could also serve as channels for developing greater care for ecologically vital but threatened areas like the rainforests of the Amazon and the Congo Basin. Forming greater solidarity in this way will not solve climate justice, but it can be one humble step along the way. It could create a greater sense of responsibility among those in the Global North for environmental damage impacting everyone, but impacting the Global South faster and more acutely. 


\section{Extractivism and integral human development}

As a method of forestalling climate change, focusing on the extraction of hardrock minerals in contradistinction to continued extraction of fossil fuels exemplifies the dominance of a paradigm referred to as extractivism. Naomi Klein $(2014,169)$ describes it as:

...a nonreciprocal, dominance-based relationship with the earth, one purely of taking. It is the opposite of stewardship, which involves taking but also taking care that regeneration and future life continue. Extractivism is the mentality of the mountaintop remover and the oldgrowth clear-cutter. It is the reduction of life into objects for the use of others, giving them no integrity or value of their own-turning living complex ecosystems into 'natural resources.'

Extractivism is based on continuously removing more, and more, and more from the earth. As climate change poses an existential threat to humanity, we make the transition from extracting fossil fuels to extracting hardrock minerals to advance renewable energy technologies, but we never stop extracting. The places where the minerals are found become what Auciello $(2019,7)$ calls "new zones of sacrifice" while "the extractivist model expands, now masked behind the veil of meeting the material needs of the transition." A substantial impetus to extractivism has been the ascendency of neoliberalism, an aggressive, no-holds-barred, version of capitalism described by Gerardo Rénique (2006, 37), writing in a Latin American context, as capitalismo salvaje (savage capitalism). It has been instrumental in empowering the multinational corporations running major mining operations and in enabling the system allowing mined goods to flow through the global supply chain and acquire separation from the harms done at local mining sites (see Princen 2002).

The World Bank has encouraged the adoption of neoliberal policies and it has also been an impetus to the promotion of mining in the Global South (Holden and Jacobson 2012, 41). Two influential World Bank publications in the early 1990s made this pattern apparent. The Strategy for African Mining (1992) argued against public ownership of mining companies in developing countries and emphasized mining projects aimed primarily at production for export. Two years later, the Principal Mining Officer of the World Bank published "Strategies to Attract New Investment for African Mining," Strongman 1994, which made it clear that the World Bank's emphasis was on opening up the mining sector in Africa to foreign direct investment by multinational mining companies (Strongman 1994). Although these reports were focused on Africa, they had an impact on mining codes across the entire Global South. For example, the Philippine Mining Act of 1995 contained incentives to encourage mining such as a four-year income tax holiday, tax and duty-free capital equipment imports, 
value-added tax exemptions, income tax deductions for losses, and accelerated depreciation (Holden and Jacobson 2012, 41). It also guaranteed the right of repatriation of the entire profits of the investment and guaranteed no mining project would ever be expropriated. Mining codes like this justify these incentives based on the premise that economic activity generated will, somehow, trickle down to the poor. This is a highly problematic strategy. Their tax incentives produce minimal revenue for their host country (188), modern capital-intensive methods of mining produce minimal employment (187), and the environmental effects of mining degrade natural resources relied upon by the rural poor and thrust them from subsistence into destitution (205).

What the extractivist paradigm never contemplates is a cessation of extraction. The idea of removing less from the earth and getting more out of what has already been extracted-or changing consumption patterns-is never considered. It is in this context that recycling becomes crucial. "The billions of tons of material already mined and circulating in cities and factories or lying in landfills," wrote Payal Sampat (2003, 111), "can serve the same functions as underground ore, with far fewer ecological costs." Many of the metals required for renewable energy are highly recyclable (Dominish, Florin, and Teske 2019, 16). Instead of mining virgin ore deposits, with all the environmental effects involved, these metals could be acquired through recycling, which is also more labor-intensive than mining and thus creates more jobs (Auciello 2019, 22). Uranium can also be recycled. When spent nuclear fuel is removed from a nuclear reactor it still has some fissionable material left and can be subjected to a process separating out reusable uranium and plutonium from non-recoverable waste products. Fuel recycling reduces the volume of final waste by a factor of five, but the cost of a kilogram of reprocessed fuel is approximately nineteen times more than the cost of a kilogram of natural uranium (Percebois $2003,102)$. Other types of recycling are similarly expensive. None of these outcomes aligns with neoliberal extractivism or the consumption habits of those in the Global North.

The argument about whether to use fossil fuels or mining-dependent renewable energy technologies may be missing a bigger point: on a planet with finite natural resources, is adherence to an economic paradigm requiring continuous growth acceptable? The question is especially urgent given how the extractivist model driving the production of these resources also drives continued poverty, environmental vulnerability, and violent conflict in the Global South.

To Pope Francis $(2015, \mathbb{\$} 109)$, the neoliberal model is problematic because "by itself, the market cannot guarantee integral human development and social inclusion." Modern neoliberal capitalism is "the mindset of those who say: let us allow the invisible forces of the market to regulate the economy and consider their impact on society and nature as collateral damage" $(\$ 123)$. This is unacceptable because "the environment is one of 
those goods that cannot be adequately safeguarded or promoted by market forces" $(\$ 190)$. Francis's ideas echo those found in a letter from the Latin American Provincials of the Society of Jesus $(1997,48)$ articulating their opposition to this economic paradigm: "Neoliberalism is a radical conception of capitalism that tends to absolutize the market and transform it into the means, the method, and the end of all intelligent and rational behavior."

A hallmark of contemporary Catholic social teaching is that technocratic and market approaches cannot meet requirements for human flourishing. These approaches do not adequately factor in either the value of the environment as a good in itself or the conflicts associated with some economic practices. Given that conflict is related to mining in the Global South, and how conflict is compounded by effects of climate change, integral human development in the mining sector is closely related to peacebuilding. A pastoral letter from the Latin American Episcopal Council CELAM (Consejo Episcopal Latinoamericano) 2018 ties these points together well. The letter criticizes the extractivist model driving mining development for its "utilitarian mindset... in service to the idolatry of capital," and outlines this model's impacts on the environment, continued poverty, and socio-environmental conflicts (CELAM 2018, \$28-46). As a remedy, the letter advocates for a "radical change in the understanding and practice of the economy" and a shift to new models of development in line with integral human development (\$103-8).

Clemens Sedmak's essay in this book offers further analysis of mining and integral human development through the lens of Laudato Si. According to Sedmak, the most important contribution that the ethics of integral human development could make in terms of the mining industry is a rejection of maximization of profits as an ultimate goal. He builds this claim from Laudato Si's observation that profit is illegitimate when it does not advance the integral development of the human person or observe the preferential option for the poor, and that care for creation is inseparable from both of those goals. Integral human development, according to Sedmak, introduces a mandate for restraint that is absent from the neoliberal model of unlimited growth and which demands that the human flourishing of the communities impacted by mining be given priority over profit maximization. This would include ecological protection ensuring communities' lands are not unjustly despoiled. This would also curb global climate change and help prevent further environmental degradation.

Picking up the theme of Catholic social teaching demanding multifaceted, integral approaches to problems, such as with the model of integral human development, Gerard Powers $(2017,8)$ suggests the need to form a model of integral peacebuilding. Climate change drives mining; mining impacts conflict vulnerability, damages fragile ecologies on which communities depend, and introduces potentially harmful economic development strategies; and these instabilities make those communities more vulnerable to climate change effects, which in turn exacerbates conflict and creates 
potentially new sources for it. This chain indeed demands that peacebuilders practice integral approaches challenging the extractivist paradigm, and that are sensitive to climate change and married to development efforts in line with integral human development.

\section{Violence against environmental defenders}

In 2007, this chapter's first author was preparing to interview Bishop Gabriel Penate, Bishop of the Apostolic Vicariate of Izabal, in Puerto Barrios, Guatemala, about the local activities of a Canadian mining company. As the interview was starting, the Canadian ambassador to Guatemala telephoned Bishop Penate and informed him there were Canadian anti-mining activists in Guatemala and that he should not talk to them (Holden and Jacobson 2012, 50). This incident exemplifies how those with interests in mining operations are willing to employ intimidation and pressure against anyone resisting their agenda.

Such intimidation frequently transitions to direct violence. One of the most disturbing aspects of the socio-environmental conflicts associated with hardrock mining are assassinations and other forms of violence against human rights and environmental activists. In 2019, according to Global Witness $(2020,6), 50$ of 212 murdered land and environmental defenders were opposing mining, the deadliest sector. Examples of this sort of violence include a 2018 incident in Malawi where thirteen people were killed by the police while protesting air and water pollution from a copper smelting plant (Global Witness 2019, 34). And in Colombia between 2015 and $2019,44 \%$ of attacks against activists and land defenders were connected to five extractive companies (Business and Human Rights Resource Center 2020, 1).

According to Victoria Tauli-Corpus, the United Nations Special Rapporteur on the rights of indigenous people, killings of environmental activists worsen the problem of climate change:

This violence is a human rights crisis, but it is also a threat to everyone who depends on a stable climate. Land and environmental defenders are among the best stewards of the world's great forests and biodiversity, and when their rights are trampled, it is often to make way for environmentally destructive logging, mining, or plantations. Protecting indigenous land rights defenders is therefore not only a human rights imperative-but also urgent to mitigating the climate crisis. (quoted in Global Witness 2019, 26)

Querida Amazonia (Francis 2020, $\mathbb{1 4}$ ) is direct on this issue, listing criminalization of protest and killings of people who oppose projects among the crimes committed by businesses in the Amazon. And it is more common to see the issue taken up by local Catholic bodies and 
on-the-ground actors. José Bayardo Chata Pacoricona's chapter describes how a significant part of Derechos Humanos y Medio Ambiente-Puno's legal defense work involves laws effectively criminalizing human rights and environmental protesters, and justifying violence against them. The Catholic Church in Colombia has lobbied the government to better defend social leaders and environmental protestors facing violence, threats, and displacement from mining operations (Fraser 2020). The Pan-Amazonian Ecclesial Network (2019) issued a statement urging national leaders and the international community to protect and defend peasants, indigenous peoples, and others facing violence and threats while trying to defend the earth and their communities. And in May 2020, CINEP/PPP, a Jesuit-run organization in Bogotá, held a virtual event to call attention to the way the COVID-19 pandemic was increasing the vulnerability of social leaders and bringing about an increase in violence against them. ${ }^{2}$

These examples show how regional, national, and local Catholic groups actively denounce and act against violence against those trying to defend their communities and ecologies against damaging activities like mining. They do so as an act of peacebuilding, and their praxis and witness provide vital contributions to the corpus of Catholic social tradition and join the global work of resisting climate change in real and substantive ways.

\section{Uranium mining, nuclear arms, and global insecurity}

As noted above, uranium mining may have the highest environmental cost of any form of mining because radioactivity cannot be mitigated as can some other mining byproducts. Though radioactivity is only one factor among many, the slow violence done to indigenous peoples in the American West by uranium mining testifies to this (see Fegadel 2020). But another issue is the specter of nuclear arms. William Perry, former U.S. Secretary of Defense, contends that the threat of nuclear war is now the greatest it has been since the Cold War (Haberman 2018). While most uranium is used for peaceful purposes, and despite major producers like Australia and Canada having strict measures to control uranium they sell, the risk of materials being channeled to weapons development is ever-present. Security of nuclear power facilities is a key concern. Reliance on nuclear energy to forestall climate change could increase the number of nuclear plants in countries without strong regulatory or security infrastructures to control weapons-grade materials at those plants. Vulnerability to cyberattacks, sabotage, or theft also remains significant in several nations already having nuclear capability (NTI 2020, n.p.).

Unlike many materials needed for clean energy technology, uranium is not predominantly mined in the Global South. Still, some of these countries, like Gabon or Niger, have been caught in the fray of the nuclear arms race. For example, after years under colonial rule and feeding into the nuclear ambitions of colonial powers, especially France, independent Niger asserted 
its independence by dealing with business partners such as Muammar Gaddafi, who became a broker to others (George 2019, 198). Furthermore, low market prices for uranium have prevented Niger from realizing significant economic benefits, leaving the country with a legacy of instability, fueling ongoing internal conflict, such as revolts by Tuareg people in northern Niger (199-201).

The Catholic record on nuclear weapons is well-established. Since Pacem in Terris (John XXIII 1963) the Catholic Church has been a leading voice on the morality of nuclear arms. The specifics of the church's teaching have evolved over the decades, but disarmament has always remained the ultimate goal (see Powers 2015). Pope Francis (2019) took the unprecedented step of calling even the possession of nuclear weapons immoral. While the church's teaching on disarmament is clear, uranium mining as an alternative to fossil fuels is more complicated. And Catholic voices have not always been strong about connecting local concerns with uranium mining, like effects of radioactivity on miners, with broader peace and security concerns like nuclear proliferation.

One recent analysis by a group of Catholic ethicists does demonstrate an integrated perspective about climate change, nuclear energy, uranium mining, and weapons proliferation. It concluded that nuclear power is unsuitable as a primary strategy for limiting climate change because of the time it would take to expand nuclear energy capacity and the diversion of resources from developing renewable energy (Biviano et al. 2016, 21-22). The same analysis also raised cautions about the byproducts of nuclear energy, specifically health effects from radioactivity, safety concerns about reactor malfunctions, and potential arms proliferation (19-20). This position helps establish a baseline of skepticism in Catholic thinking about nuclear energy.

And that skepticism can be seen in practice, if not necessarily with the full range of integrated perspective. For example, as noted above, the Navajo people of the southwestern United States have suffered a decades-long legacy of environmental, cultural, and social violence in connection to uranium mining. The US Catholic community in New Mexico, the center of many of these issues, has been active in resisting ongoing uranium mining and seeking justice for past harms. Over twenty years ago, the state's Catholic bishops issued a pastoral statement on global climate change, energy, and the unique related challenges for their state (Roman Catholic Bishops of New Mexico 1998). They argued that the climate crisis should not be compounded by mining projects worsening local ecological vulnerabilities or disproportionately affecting marginalized peoples. In 2015, the Office of Peace, Justice, and Creation Stewardship of the Diocese of Gallup offered testimony at a public hearing about a permit to resume uranium mining at Mount Taylor. The testimony was offered on behalf of "concerned people of faith in Catholic communities in Cibola County... who continue to suffer adverse health and environmental impacts from past 
decades of uranium mining, yet to be satisfactorily remediated to bring an end to continuing contamination of life-sustaining water, land and air in the Mount Taylor region" (Cecchini 2015). In both cases there is a clear focus on local impacts, and from the bishops, concern about the broader issue of climate change; however, neither statement took the step of also connecting those concerns to ethical questions about nuclear proliferation.

Catholic leaders also intervened on uranium mining in Malawi beginning in 2007. Paladin Energy, an Australian company, was in the process of opening the Kayelekera Uranium Mine for production, when the Catholic Commission for Justice and Peace of the Episcopal Conference of Malawi (CCJP) joined a group of NGOs filing an injunction alleging Paladin's environmental impact assessment failed to account for some of the unique hazards of uranium mining (CathNews.com 2007). The mine opened in 2009 and went into a care and maintenance phase in $2014 .^{3}$ In the year before it closed, Norwegian Church Aid and Catholic Commission for Justice and Peace Malawi (2013, 10, 28-30, 31-32) published a joint report focused particularly on economic issues with the Kayelekera project, and at several points it brought up the problem of displaced persons, repeatedly highlighting inadequate resettlement processes, losses of livelihoods, and community disruption as some of the chief problems of the country's mining sector. In a separate report, Catholic Commission for Justice and Peace Malawi (2014) compared mining displacement in Malawi with other countries in southern Africa. Like the 2013 report, this report developed legislation and policy recommendations, but did so specifically with regard to internal displacement caused by mining and expanded to consider environmental as well as social and economic issues. In recent years, such factors have substantially increased the potential for violent conflict in Malawi (Human Rights Watch 2016; Kishindo and Mvula 2017). Yet as in New Mexico, while Catholic leaders in Malawi dealt with important local and national issues, they did not bridge those issues with the problem of nuclear arms uniquely connected to uranium mining.

These two cases demonstrate how uranium mining, like nearly all hardrock mining, has had great difficulty meeting the standards of sustainability and justice required by Catholic social teaching. But they also show inconsistency in Catholic voices about connecting those critiques to the extra worry of nuclear weapons that gives questions about uranium mining distinct urgency. Nevertheless, even if it has not been consistently expressed, the framework of Catholic social tradition does offer a structure for integrating peace, sustainability, and justice in the analysis of uranium mining.

\section{Conclusion}

The hydrometeorological hazards posed by climate change pose a substantial threat to hardrock mines, and concerns about climate change may 


\section{2}

lead to an increase in metals mining because it is critical for clean energy. These realties have important implications for climate change, justice, and peace: disparate impacts on the Global South compared to the Global North; the maintenance of a neoliberal extractivist paradigm perpetuating injustices and yielding inadequate models of development; rises in violence against activists defending human rights and the environment; and questions about uranium mining, which introduces unique environmental hazards and risks contributing to nuclear proliferation.

Catholic social thought and the theory and praxis of peacebuilding offer responses to these issues. They speak loudly and clearly to the need for climate justice and greater solidarity with vulnerable peoples suffering violent conflict exacerbated by mining. Catholic social thought and peacebuilding also stringently interrogate the extractivist model and offer an alternate vision of integral human development. Catholic leaders and organizations actively engage the problem of violence against human rights and environmental defenders and take action to alleviate it. And lastly, the Catholic Church is a strong advocate for nuclear non-proliferation and disarmament. It is also a source of vigorous action at local and regional levels defending communities from the effects of uranium mining, though Catholic actors could do more to connect that advocacy and action to issues of nuclear weapons. Hardrock mining is very much at the center of climate change and conflict discussions, and Catholic teaching and peacebuilding can make important contributions to the conversation.

\section{Notes}

1 A recent example is the Carr Wildfire in California in July 2018, which nearly destroyed a water treatment facility built to mitigate acid drainage from the Iron Mountain Mine (closed in 1963).

2 https://www.cinep.org.co/Home2/component/k2/789-lideres-sociales-blanco-deviolencia-en-cuarentena.html.

3 When the mine was closed in 2014, the retrenchment of workers occurred with repressive force from armed security and left the mine without capacity to begin rehabilitation, monitor and mitigate radiation, or deal with a near-overflowing tailings dam (see Nyirenda, 2014).

\section{References}

Ali, Saleem H. 2003. Mining, the Environment, and Indigenous Development Conflicts. Tucson, AZ: University of Arizona Press.

Auciello, Benjamin Hitchcock. 2019. A Just(ice) Transition is a Post-Extractive Transition. London: War on Want and London Mining Network. https:// waronwant.org/sites/default/files/Post-Extractivist_Transition_WEB_0.pdf.

Bell, Derek. 2013. "How Should We Think About Climate Justice?" Environmental Ethics 35, no. 2: 189-208. 10.5840/enviroethics201335217.

Biviano, Erin Lothes, David Cloutier, Elaine Padilla, Christiana Z. Peppard, and Jame Schaeffer. 2016. "Catholic Moral Traditions and Energy Ethics for the 
Twenty-First Century." Journal of Moral Theology 5, no. 1: 1-36. https:// jmt.scholasticahq.com/article/11306-catholic-moral-traditions-and-energy-ethicsfor-the-twenty-first-century.

Business and Human Rights Resource Center. 2020. "Business and Human Rights Defenders in Colombia.” https://media.business-humanrights.org/media/ documents/files/Business_Human_Rights_Defenders_in_Colombia.pdf.

CathNews.com. 2007. "Malawi Catholics Seek Injunction Against Aussie Uranium Mine.” April 9, 2007. https://cathnews.com/cathnews/12687-malawi-catholicsseek-injunction-against-aussie-uranium-mine.

Catholic Commission for Justice and Peace Malawi. 2014. Land Displacement, Involuntary Resettlement and Compensation Practice in the Mining Sector: A Comparative Analysis of Legal and Policy Frameworks in Southern Africa. https://www.ecmmw.org/new/wp-content/uploads/2014/12/Report-on-LandDisplacement-Inviluntarry-Resttlement-and-Compensation-Practices.pdf.

Cecchini, Rose Marie. 2015. “Testimony on Rio Grande Resources Standby Permit from 2010" (Post-Hearing Public Comments, Cibola County, New Mexico, May 2015). http://www.emnrd.state.nm.us/mmD/MARP/documents/MtTaylor_Rev101_PostHearingCommentsfromthePublic.pdf.

CELAM (Consejo Episcopal Latinoamericano). 2018. Discípulos Misioneros: Custodios de Nuestro Hogar Común: Discernimiento a la Luz de la Encíclica Laudato Si'. Bogotá: Consejo Episcopal Latinoamericano, CELAM.

Dominish, Elsa, Nick Florin, and Sven Teske. 2019. "Responsible Minerals Sourcing for Renewable Energy." Report prepared for Earthworks by the Institute for Sustainable Futures, University of Technology Sydney. https://www.earthworks.org/ cms/assets/uploads/2019/04/MCEC_UTS_Report_lowres-1.pdf.

Environmental Justice Atlas. n.d. Accessed December 4, 2019. https://ejatlas.org/.

Fegadel, Averi R. 2020. Toxic Colonialism and Green Victimization of Native Americans: An Examination of the Genocidal Impacts of Uranium Mining. Ph.D. diss., University of South Florida. https://scholarcommons.usf.edu/etd/ 8194/.

Fernandes, Horst M., Mariza R. Franklin, and Lene H. Veiga. 1998. “Acid Rock Drainage and Radiological Environmental Impacts: A Study Case of the Uranium Mining and Milling Facilities at Pocos de Caldas." Waste Management 18, no. 3 : 169-181. 10.1016/S0956-053X(98)00019-1.

Francis. 2015. Laudato Si'. http://www.vatican.va/content/francesco/en/encyclicals/ documents/papa-francesco_20150524_enciclica-laudato-si.html.

Francis. 2019. “Address at the Hiroshima Peace Memorial.” November 24, 2019. http://www.vatican.va/content/francesco/en/messages/pont-messages/2019/documents/papa-francesco_20191124_messaggio-incontropace-hiroshima.html.

Francis. 2020. Querida Amazonia. http://www.vatican.va/content/francesco/en/apost_ exhortations/documents/papa-francesco_esortazione-ap_20200202_querida-amazonia.html.

Fraser, Barbara. 2018. "Church Urges Colombian Government to Protect Local Leaders Under Threat.” Catholic News Service, September 5, 2018. Accessed in National Catholic Reporter. https://www.ncronline.org/news/world/churchurges-colombian-government-protect-local-leaders-under-threat.

George, William P. 2019. Mining Morality: Prospecting for Ethics in a Wounded World. Lanham, MD: Lexington Books, 2019. 


\section{William N. Holden \& Caesar A. Montevecchio}

Global Witness. 2019. Enemies of the State? How Governments and Business Silence Land and Environmental Defenders. London: Global Witness. https:// www.globalwitness.org/en/campaigns/environmental-activists/enemies-state/.

Global Witness. 2020. Defending Tomorrow: The Climate Crisis and Threats Against Land and Environmental Defenders. London: Global Witness. https:// www.globalwitness.org/en/campaigns/environmental-activists/defending-tomorrow/.

Haberman, Clyde. 2018. “This Is Not a Drill': The Threat of Nuclear Annihilation.” New York Times, May 13, 2018. https://www.nytimes.com/2018/ 05/13/us/nuclear-threat-retro-report.html.

Holden, William N. 2015. "Mining Amid Typhoons: Large-Scale Mining and Typhoon Vulnerability in the Philippines." The Extractive Industries and Society 2: 445-461. 10.1016/j.exis.2015.04.009.

Holden, William N., and R. Daniel Jacobson. 2012. Mining and Natural Hazard Vulnerability in the Philippines: Digging to Development or Digging to Disaster? London: Anthem Press. 10.7135/UPO9781843313960.

Human Rights Watch. 2016. “They Destroyed Everything': Mining and Human Rights in Malawi.” September 27, 2016. https://www.hrw.org/report/2016/09/ 27/they-destroyed-everything/mining-and-human-rights-malawi.

John XXIII. 1963. Pacem in Terris. https://www.vatican.va/content/john-xxiii/en/ encyclicals/documents/hf_j-xxiii_enc_11041963_pacem.html.

Kishindo, Paul, and Peter Mvula. 2017. "Malawi's Land Problem and Potential for Rural Conflict.” Journal of Contemporary African Studies 35, no. 3: 370-382. 10.1080/02589001.2017.1342784.

Klein, Naomi. 2014. This Changes Everything: Capitalism vs The Climate. Toronto: Knopf.

Latin American Provincials of the Society of Jesus. 1997. "Letter and Study Document on Neoliberalism in Latin America." Promotio Justitae 67: 43-60. https://www.sjesjesuits.global/media/2021/02/PJ_067_ENG.pdf.

Macfarlane, Allison. 2003. "Is Nuclear Energy the Answer?" In Fueling the Future: How the Battle Over Energy is Changing Everything, edited by Andrew Heintzman and Evan Solomon, 127-151. Toronto: Anansi Press, 2003.

Marshall, Eliot. "Is the Friendly Atom Poised for a Comeback?" Science 309, no. 5738 (2005): 1168-1169. 10.1126/science.309.5738.1168.

Milly, P.C.D., Julio Betancourt, Malin Falkenmark, Robert M. Hirsch, Zbigniew Z. Kundzewicz, Dennis P. Lettenmaier, and Ronald J. Stouffer. 2008. "Stationarity is Dead: Whither Water Management?” Science 319, no. 5863: 573-574. 10.1126/ science. 1151915.

Morrison, Robert. 2001. "Global Nuclear Markets in the Context of Climate Change and Sustainable Development." In Canadian Nuclear Energy Policy: Changing Ideas, Institutions, and Interests, edited by G. Bruce Doern, Arlsan Dorman, and Robert W. Morrison, 34-51. Toronto: University of Toronto Press. http://www.jstor.org/stable/10.3138/9781442672260.6.

National Academies of Sciences, Engineering, and Medicine. 2016. Attribution of Extreme Weather Events in the Context of Climate Change. Washington, DC: The National Academies Press. 10.17226/21852.

Noriyoshi, Takemura. 2020. "The Hottest Chaos of Cobalt Mining in the Democratic Republic of Congo: 'Triadic Abyss' of Human Rights Abuses, Environmental 
Pollution, and Illegal Global Trade." Toin University of Yokohama Research Bulletin 42: 35-42. 10.50937/00000361.

Norwegian Church Aid and Catholic Commission for Justice and Peace (Malawi). 2013. Malawi's Mining Opportunity: Increasing Revenues, Improving Legislation. Lilongwe, Malawi: Norwegian Church Aid. https://curtisresearch.org/malawismining-opportunity-increasing-revenues-improving-legislation/.

NTI Nuclear Security Index. n.d. Accessed June8, 2021. https://www.ntiindex.org/. Nyirenda, William. 2014. "Paladin Lies to Malawi Government on its Kayelekera Uranium Mine." Environmental Justice Organisations, Liabilities and Trade, April 2, 2014. http://www.ejolt.org/2014/04/paladin-lies-to-malawi-governmenton-its-kayelekera-uranium-mine/.

Pan-Amazonian Ecclesial Network (Red Eclesial Panamazónica). 2019. "Situación de urgencia: amenaza de muerte a líderes en Colombia, llamado internacional a proteger la vida de los defensores.” January 21, 2019. http://redamazonica.org/ 2019/01/situacion-de-urgencia-amenaza-de-muerte-a-lideres-en-colombia-llamado-internacional-a-proteger-la-vida-de-los-defensores/.

Percebois, Jacques. 2003. "The Peaceful Uses of Nuclear Energy: Technologies of the Front and Back-Ends of the Fuel Cycle." Energy Policy 31, no. 2: 101-108. 10.1016/S0301-4215(02)00035-6.

Powers, Gerard F. 2015. "From Nuclear Deterrence to Disarmament: Evolving Catholic Perspectives." Arms Control Today 45. https:/www.armscontrol.org/ act/2015-05/features/nuclear-deterrence-disarmament-evolving-catholic-perspectives.

Powers, Gerard F. 2017. "Toward an Integral Catholic Peacebuilding." Journal of Social Encounters 1: 1-13. https:/digitalcommons.csbsju.edu/social_encounters/ vol1/iss $1 / 2 /$.

Princen, Thomas. 2002. "Distancing: Consumption and the Severing of Feedback." In Confronting Consumption, edited byThomas Princen, Michael Maniates, and Ken Conca, 103-132. Cambridge, MA: MIT Press. 10.7551/mitpress/2097.001. 0001.

Rénique, Gerardo. 2006. "Strategic Challenges for Latin America's Anti-Neoliberal Insurgency." In Dispatches from Latin America: On the Frontlines against Neoliberalism, edited by Teo Ballvé and Vijay Prashad, 35-46. Cambridge, MA: South End Press.

Richter, Burton. 2006. "Between 2 Devils." IAEA Bulletin 47, no. 2: 14-17. https://www.iaea.org/sites/default/files/publications/magazines/bulletin/bull472/47204791417.pdf.

Ripley, Earle A., E. Robert Redmann, Adèle A. Crowder, Tara C. Ariano, Catherine A. Corrigan, Robert J. Farmer, L. Moira Jackson. 1996. Environmental Effects of Mining. Boca Raton, FL: Routledge. 10.1201/9780203757147.

Roman Catholic Bishops of New Mexico. 1998. "Partnership for the Future." https://archdiosf.org/partnership-for-the-future.

Sampat, Payal. 2003. "Scrapping Mining Dependence." In State of the World 2003: A Worldwatch Institute Report on Progress Towards a Sustainable Society, edited by Lisa Starke, 110-129. London: Routledge. 10.4324/9781849776257.

Strongman, John. 1994. "Strategies to Attract New Investment for African Mining.” https://documents1.worldbank.org/curated/en/349851468767422230/ pdf/multi-page.pdf. 


\section{William N. Holden \& Caesar A. Montevecchio}

Thomas, Patricia A., and Thomas E. Gates. 1999. "Radionuclides in the LichenCaribou-Human Food Chain Near Uranium Mining Operations in Northern Saskatchewan, Canada." Environmental Health Perspectives 107, no. 7: 527-537. 10.1289/ehp.99107527.

Wallace-Wells, David. 2019. The Uninhabitable Earth: Life After Warming. New York: Tim Duggan Books.

World Bank. 1992. Strategy for African Mining. World Bank Technical Paper Number 181, Africa Technical Department Series. Washington, DC: World Bank. https://documents1.worldbank.org/curated/en/722101468204567891/pdf/ multi-page.pdf. 